\title{
Menghilangkan Alat Bukti oleh Penyidik Tindak Pidana Korupsi Sebagai Upaya Obstruction of Justice
}

\author{
Muh Sutri Mansyah ${ }^{1}$ *, La Ode Bunga Ali ${ }^{2}$ \\ ${ }^{1}$ Program Studi Magister Ilmu Hukum, Fakultas Hukum, Universitas Brawijaya. JL. M.T Haryono \\ No.167, Malang, Indonesia. \\ ${ }^{2}$ Fakultas Hukum, Universitas Dayanu Ikhsanuddin. Baubau, Sulawesi Tenggara, Indonesia. \\ * Korespondensi Penulis. E-mail: muhsutrimansyahr@gmail.com, Hp: 085230801605
}

\begin{abstract}
Abstrak
Artikel ini bertujuan untuk mengetahui dan menganalisis mengenai menghilangkan alat bukti oleh penyidik tindak pidana korupsi sebagai upaya obstruction of justice, disini penulis menggunakan jenis penelitian yuridis normatif dengan pendekatan perundang-undangan dan pendekatan kasus, hal ini dilatar belakangi setiap kasus tindak pidana korupsi tentunya akan dimulai dari proses penyelidikan, penyidikan, penuntutan, pemeriksaan di pengadilan, sampai penjatuhan vonis dan pelaksanaan putusan. sebagaimana hal tersebut merupakan proses dalam sistem peradilan pidana, suatu kasus dapat ditindak lanjuti berdasarkan minimal 2 (dua) alat bukti, namun muncul permasalahan jika ternyata alat bukti diduga dihilangkan oleh penyidik, maka akan timbul pertanyaan apakah dengan menghilangkan alat bukti oleh penyidik sebagai upaya obstruction of justice, maka hasil penelitian bahwa menghilangkan alat bukti dapat termasuk upaya obstruction of justice yang merupakan perbuatan tindak pidana dan penyidik harus bertangungjawab secara pidana menurut pasal 21 Undang-Undang No 20 Tahun 2001 perubahan atas Undang-Undang No 31 Tahun 1999 tentang Pemberantasan Tindak Pidana Korupsi.
\end{abstract}

Kata Kunci: menghilangkan; penyidik; alat bukti; tindak pidana korupsi; obstruction of justice

\section{Eliminating Evidence by Corruption Investigators as Obstruction of Justice Efforts}

\begin{abstract}
This article aims to find out and analyze the elimination of evidence by corruption investigators as an attempt to obstruction of justice, here the author uses normative juridical research with a legal approach and a case approach, this is motivated by every case of corruption from the process of investigation, investigation, prosecution, examination in the court, to the verdict and implementation of the verdict. as it is a process in the criminal justice system, a case can be followed up based on at least 2 (two) evidence, but problems arise if it turns out that the evidence is allegedly removed by the investigator, the question will arise whether by removing the evidence by the investigator as an obstruction effort of justice, the results of the study that removing evidence could include efforts to obstruction of justice which are acts of crime and investigators must be criminally responsible according to Article 21 of Act No. 20 of 2001 amendment to Law No. 31 of 1999 concerning Eradication of Criminal Acts Corruption.
\end{abstract}

Keywords: eliminate; investigator; evidence; criminal acts of corruption; obstruction of justice 
EKSPOSE: Jurnal Penelitian Hukum dan Pendidikan, 18 (2), Desember 2019 - 878

Muh Sutri Mansyah, La Ode Bunga Ali

\section{PENDAHULUAN}

Dalam penegakkan tindak pidan korupsi tentunya dilakukan oleh lembaga yang memiliki kewenangan seperti yang diketahui adapun lembaga yang dimaksud ialah Kepolisian, Kejaksaan, Komisi Pemberantasan Korupsi (KPK), dan Pengadilan. Mengenai proses pengusutan kasus tindak pidana korupsi awal mulanya dimulai dari penyelidikan, penyidikan, penuntutan, mengadili, hingga memutus perkara. Keempat lembaga tersebut memiliki batasan sampai dimana melakukan penegakkan hukum khusus tindak pidana korupsi seperti Kepolisian hanya dapat melakukan penyelidikan dan penyidikan, Kejaksaan diberikan kewenangan untuk menangani kasus tindak pidana khusus dimulai dari melakukan penyelidikan, penyidikan, dan penuntutan, KPK merupakan lembaga yang baru lahir diera reformasi yang sebenarnya memiliki kewenangan sama dengan kepolisian dan kejaksaan namun karena kedua lembaga tersebut dianggap belum efektif dalam menjalankan penegakan hukum dalam bidang tindak pidana korupsi dan publik kurang memiliki kepercayaan. Maka, lembaga antirasuah lahir sebagai lembaga pembantu yang bertujuan mengembalikan kepercayaan publik terhadap 2 institusi tersebut atau dapat disebut auxilary organ, maka KPK memiliki kewenangan melakukan penyelidikan, penyidikan, dan penuntutan. Sedangkan, pengadilan tentunya sebagai lembaga yang mengadili terdakwa dan memutus perkara tindak pidana korupsi.

Adapun awal mula pengusutannya kasus tindak pidana korupsi sangat ditentukan oleh alat bukti yang dimiliki oleh penyidik, alat bukti yang dimaksud diatur dalam Pasal 184 ayat (1) KUHAP ialah keterangan ahli, keterangan saksi, surat, petunjuk, dan keterangan terdakwa. Meskipun telah ada lima alamt bukti namun ada perluasan atau penambahan alat bukti khususnya dalam tindak pidana korupsi yang didasarkan pada alat bukti petunjuk sebagaimana diatur dalam Pasal 26A UU No. 31 Tahun 1999 yang diubah dengan UU No. 20 Tahun 2001 tentang Pemberantasan Tindak Pidana Korupsi yaitu berupa informasi yang diucapkan, dikirim, diterima, atau disimpan secara elektronik dengan alat optik, dokumen (rekaman data atau informasi yang dilihat, dibaca, dan atau didengar).

Belum lama ini ada seorang penyidik diduga menghilangkan alat bukti seperti yang dikutip oleh salah satu media, idntimes.com (08 Feb 2019), "Pelaku yang diduga menyobek buku itu adalah perwira menengah dari kepolisian yakni Ronald Rolandy dan Harun. Selain menyobek, keduanya juga diduga menghapus beberapa catatan di buku tersebut dengan tip ex. Bagian catatan yang dihilangkan, diduga memuat data penerimaan uang bagi Kapolri Jenderal (Pol) Tito Karnavian".

Hal ini tentunya akan menghambat proses peradilan yang dilakukan maka penulis akan melakukan penelitian mengenai perbuatan penyidik seperti contoh kasus diatas, Sehingga penulis mengangkat judul "Menghilangkan Alat Bukti Oleh Penyidik Tindak Pidana Korupsi Sebagai Upaya Obstruction Of Justice". Dari latar belakang yang telah jelaskan oleh penulis, maka dapat ditemukan permasalahan hukum, yaitu: Apakah tindakan penyidik tindak pidana korupsi menghilangkan alat bukti dapat dikatakan sebagai tindakan obstruction of justice?

\section{METODE}

Dalam penelitian ini menggunakan metode penelitian yuridis normatif dengan pendekatan perundang-undangan (Statute approach) dan pendekatan kasus, bahan hukum primer yaitu Pasal 21 Undang-Undang Nomor 20 Tahun 2001 perubahan atas Undang-Undang Nomor 31 Tahun 1999 tentang Pemberantasan Tindak Pidana Korupsi dan bahan hukum sekunder yaitu buku-buku, Jurnal-jurnal hukum, Surat kabar, Pendapat para sarjana, Legal Dictionary, Black's Law Dictionary. Dalam penelitian ini Teknik Memperoleh Bahan Hukum dilakukan dengan studi kepustakaan (library research) yang memiliki relevansi dengan peraturan perundangan yang mengatur tentang objek kajian ini. teknik analisis bahan hukum yang digunakan merupakan interpretasi sistematis dan interpretasi gramatikal.

\section{HASIL DAN PEMBAHASAN}

Pada proses peradilan pidana yang ada di indonesia, yaitu: tahap penyelidikan, tahap penyidikan, tahap penuntutan, tahap pemeriksaan pengadilan, sampai pada tahap penjatuhan putusan dan pelaksaan putusan. Dalam proses administrasi berkairan dengan masalah administrasi pemeriksaan perkara yang pertama; court administration, yang dalam hal ini berarti keadministrasian atau tertib administrasi yang harus dilaksanakan berkaitan dengan jalannya kasus tindak pidana dari tahap penyelidikan sampai pada tahap pelaksaan putusan dalam sistem peradilan pidana, dan kedua; administration of justice yang dalam 
dalam hal ini dapat berarti segala hal yang mencakup tertib hukum pidana formil dan materiil yang harus dipatuhi dalam proses penanganan perkara dan tatacara serta praktek litigasi. ${ }^{1}$

Kasus yang dikemukakan oleh penulis pada latar belakang dilakukan oleh yang diduga penyidik KPK, penyidik yang diduga merupakan penyidik yang berasal dari kepolisian, Dalam pasal 6 ayat (1) KUHAP pengertian penyidik merupakan pejabat kepolisian yang berstatus sebagai pegawai negeri sipil yang diberikan kewenangan khusus dalam undang-undang untuk melakukan penyidikan, Penyidik KPK khusus dalam perkara korupsi.Dalam perbuatan yang dilakukan ialah diduga menghilangkan alat bukti atau barang bukti, menghilangkan dalam Kamus Besar Bahasa Indonesia (KBBI) "melenyapkan, membuat supaya hilang, menghapus(kan); membersihkan, membuang supaya tidak ada lagi; meniadakan". Untuk mengetahui perbuatan penyidik yang diduga menghilangkan alat bukti atau barang bukti merupakan upaya obstruction of justice, maka penulis akan menjelaskan terlebih dahulu mengenai obstruction of justice.

Dalam tindak pidana korupsi terdapat beberapa tindak pidana lainnya seperti obstruction of justice sebagaimana memiliki arti menghala-halangi, merintangi pada proses pengadilan tindak pidana korupsi hal ini ditujukan di Undang-Undang Nomor31 Tahun 1999 jo Undang-Undang Nomor 20 Tahun 2001 tentang Pemberantasan Tindak Pidana Korupsi. Dalam upaya memahami obstruction of justice, maka perlu ditelusuri literatur yang mengkaji mengenai hal tersebut. secara etiologi terlebih dulu. Istilah obstruction of justice merupakan terminologi hukum yang berasal dari literatur Anglo Saxon, yang dalam doktrin ilmu hukum pidana di indonesia sering diterjemahkan sebagai "tindak pidna menghalangi proses hukum. ${ }^{2}$ Secara sederhana, charles boys mengatakan bahwa "obstruction of justice is the frustration of govermental purposes by violence, corruption, destruction of evidence, or deceit. ${ }^{3}$

Menurut Legal Dictionary bahwa Obstruction Of Justice adalah "an attempt to interfere with the administration of the courts, the judicial system or law enforcement officers, including threatening witnesses, improper conversations with jurors, hiding evidence, or interfering with an arrest. Such activity is a crime. (Legal Dictionary: 2019) Jika diartikan dalam terjemahan bahasa indonesia secara bebas maka, Obstruction Of Justice adalah upaya untuk mengganggu Administrasi Pengadilan, sistem peradilan atau aparat penegak hukum, termasuk mengancam saksi-saksi, tidak tepat percakapan dengan juri, menyembunyikan bukti, atau mengganggu penangkapan. Kegiatan tersebut merupakan kejahatan.

Dengan pengertian demikian, maka obstruction of justice sebenarnya tidak hanya berkaitan dengan suatu proses hukum (pidana) saja, tapi juga berkenan dengan semua aktivitas pemerintah dalam upaya mewujudkan tujuan pemerintah. Namun Kamus Hukum Black (Black's Law Dictionary) merumuskan obstruction of justice tersebut sebagai berikut: "Interfacewith the orderly administration of law and justice, as by giving false information to or withholding evidence from a police officer or prosecutor, or by harming or intimidating a witness or juror". ${ }^{4}$

Pengertian obstruction of justice yang diartikan pada Kamus Black lebih spesifik, karena berkaitan dengan the administration of law and justice . Black memaknai tindakan menghalang-halangi proses hukum (obstruction of justice) sebagai segala bentuk intervensi kepada seluruh proses hukum dan keadilan dari awal hingga proses itu selesai. Bentuk-bentuk intervensi tersebut dapat berupa memberikan keterangan palsu, menyembunyikan bukti-bukti dari kepolisian atau kejaksaan, ataupun mencelakai atau mengintimidasi para saksi atau juri (penggunaan juri pada hukum acara Anglo Saxon). ${ }^{5}$

Dalam perkara tindak pidana korupsi, tindakan meghalang-halangi proses hukum, sudah merupakan produk kejahatan yang tumbuh subur di indonesia. Bahkan Heinzpeter Znoj dalam Deep Corruption in indonesia: Discourses, Practices, Histories, menjelelaskan bagaimana korupsi terus merajalela bahkan ketika runtuhkan rezim orde baru yang korup. Berbagai tindakan yang merupakan

${ }^{1}$ Yesmil Anwar and Adang, "Sistem Peradilan Pidana: Konsep, Komponen \& Pelaksanaannya Dalam Penegakan Hukum Di Indonesia” (Widya Padjadjaran, 2009).

${ }^{2}$ Shinta Agustina, "Obstruction of Justice: Tindak Pidana Menghalangi Proses Hukum Dalam Upaya Pemberantasan Korupsi” (Themis Books, 2015).

${ }^{3}$ Charles Doyle, "Obstruction of Justice: An Overview of Some of the Federal Statutes That Prohibit Interference with Judicial, Executive, or Legislative Activities" (Library of Congress, Congressional Research Service, 2014).

${ }^{4}$ Henry Campbell Black et al., Black's Law Dictionary, vol. 196 (West Group St. Paul, MN, 1999).

${ }^{5}$ Black et al. 
bentuk-bentuk obstruction of justice tersebut ternyata dijumpai secara komprehensif dalam ketentuan normatif hukum pidana indonesia.

\section{Pengaturan Obstruction of Justice Dalam Hukum Pidana Positif di Indonesia}

Obstruction of justice dalam ketentuan hukum pidana umum (KUHP), Obstruction of Justice sebagai tindak pidana diatur dalam buku kedua, Bab VIII tentang kejahatan terhadap kekuasaan umum. Dalam bab ini diatur beberapa perbuatan yang bersifat melawan terhadap alat-alat kekuasaan negara dengan kata lain ketentuan dalam bab ini bermaksud melindungi kepentingan pemerintah, dalam arti agar organ-organ pemerintah dapat melaksanakan tugasnya, guna ketertiban umum dan keamanan masyarakat luas.

Bab ini dimulai dari Pasal 207 hingga Pasal 412, satu hal yang perlu diperhatikan terkait pengaturan obstruction of justice dalam KUHP adalah, bahwa dari sekian banyak pasal yang dapat dianalogikan sebagai tindakan obstruction of justice hanya ada satu pasal yang secara jelas menyebutkan unsur tujuan "untuk menghalang-halangi atau menyusahkan pemeriksaan penyelidikan atau penuntutan" sebagaimana terdapat dalam Pasal 221 ayat (1) sub 2e. Sementara Pasal 222 menyebutkan unsur "menghalag-halangi pemeriksaan mayat untuk pengadilan" sebagai bagian dari obstuction of justice. namun dengan melakukan kajian perbandingan hukum (legal comparative), baik terhadap ketentuan hukum pidana khusus mauapun terhadap beberapa ketentuan hukum pidan negara lainyang mengatur tentang obstruction of justice, dapat disimpulkan beberapa delik yang dirumuskan dalam bab ini merupakan tindak pidana (yang dapat) menghalangi suatu proses hukum. Namun ada beberapa pasal yang relevan seperti yang disajikan pada Tabel 1 .

Tabel 1. Pasal yang Relevan dengan Obstruction of Justice

\begin{tabular}{|c|c|c|}
\hline No & Pasal & Bunyi \\
\hline 1. & Pasal 211 & $\begin{array}{l}\text { "Barang siapa dengan kekerasan atau ancaman kekerasan } \\
\text { memaksa seorang pejabat untuk melakukan perbuatan jabatan } \\
\text { atau untuk tidak melakukan perbuatan jabatan yang sah, diancam } \\
\text { dengan pidana penjara paling lama empat tahun". }\end{array}$ \\
\hline 2. & Pasal 212 & $\begin{array}{l}\text { "Barang siapa dengan kekerasan atau ancaman kekerasan } \\
\text { melawan seorang pejabat yang sedang menjalankan tugas yang } \\
\text { sah, atau orang yang menurut kewajiban undang-undang atau atas } \\
\text { permintaan pejabat memberi pertolongan kepadanya, diancam } \\
\text { karena melawan pejabat, dengan pidana penjara paling lama satu } \\
\text { tahun empat bulan atau pidana denda paling banyak empat ribu } \\
\text { lima ratus rupiah". }\end{array}$ \\
\hline 3. & $\begin{array}{l}\text { Pasal } 216 \text { ayat } \\
\text { (1) }\end{array}$ & $\begin{array}{l}\text { "Barang siapa dengan sengaja tidak menuruti perintah atau } \\
\text { permintaan yang dilakukan menurut undang-undang oleh pejabat } \\
\text { yang tugasnya mengawasi sesuatu, atau oleh pejabat berdasarkan } \\
\text { tugasnya, demikian pula yang diberi kuasa untuk mengusut atau } \\
\text { memeriksa tindak pidana; demikian pula barang siapa dengan } \\
\text { sengaja mencegah, menghalang-halangi atau menggagalkan } \\
\text { tindakan guna menjalankan ketentuan undang- undang yang } \\
\text { dilakukan oleh salah seorang pejabat tersebut, diancam dengan } \\
\text { pidana penjara paling lama empat bulan dua minggu atau pidana } \\
\text { denda puling banyak sembilan ribu rupiah". }\end{array}$ \\
\hline 4. & Pasal 217 & $\begin{array}{l}\text { "Barang siapa menimbulkan kegaduhan dalam sidang pengadilan } \\
\text { atau di tempat di mana seorang pejabat sedang menjalankan } \\
\text { tugasnya yang sah di muka umum, dan tidak pergi sesudah } \\
\text { diperintah oleh atau atas nama penguasa yang berwenang, } \\
\text { diancam dengan pidana penjara paling lama tiga minggu atau } \\
\text { pidana denda paling banyak seribu delapan ratus rupiah". }\end{array}$ \\
\hline 5. & Pasal 218 & $\begin{array}{l}\text { "Barang siapa pada waktu rakyat datang berkerumun dengan se- } \\
\text { ngaja tidak segera pergi setelah diperintah tiga kali oleh atau atas } \\
\text { nama penguasa yang berwenang, diancam karena ikut serta } \\
\text { perkelompokan dengan pidana penjara paling lama empat bulan }\end{array}$ \\
\hline
\end{tabular}




\begin{tabular}{lll}
\hline No & Pasal & \multicolumn{1}{c}{ Bunyi } \\
\hline & & $\begin{array}{l}\text { dua minggu atau pidana denda paling banyak sembilan ribu } \\
\text { rupiah". } \\
\text { 6. }\end{array}$ \\
& "Barang siapa secara melawan hukum merobek, membikin tak \\
& dapat dibaca atau merusak maklumat yang diumumkan atas nama \\
& penguasa yang berwenang atau menurut, ketentuan undang- \\
& undang, dengan maksud untuk mencegah atau menyukarkan \\
& orang mengetahui isi maklumat itu, diancam dengan pidana \\
& penjara paling lama satu bulan dua minggu atau pidana denda \\
& paling banyak empat ribu lima ratus rupiah". \\
& "Barang siapa memberitahukan atau mengadukan bahwa telah \\
& dilakukan suatu perbuatan pidana, padahal mengetahui bahwa itu \\
& tidak dilakukan, diancam dengan pidana penjara paling lama satu \\
& tahun empat bulan."
\end{tabular}

8. Pasal 221 ayat Diancam dengan pidana penjara paling lama sembilan bulan atau (1) pidana denda paling banyak empat ribu lima ratus rupiah:

1.barang siapa dengan sengaja menyembunyikan orang yang melakukan kejahatan atau yang dituntut karena kejahatan, atau barang siapa memberi pertolongan kepadanya untuk menghindari penyidikan atau penahanan oleh penjahat kehakiman atau kepolisian, atau oleh orang lain yang menurut ketentuan undang-undang terus-menerus atau untuk sementara waktu diserahi menjalankan jabatan kepolisian;

2.barangsiapa setelah dilakukan suatu kejahatan dan dengan maksud untuk menutupinya, atau untuk menghalang-halangi atau mempersukar penyidikan atau penuntutannya, menghancurkan, menghilangkan, menyembunyikan bendabenda terhadap mana atau dengan mana kejahatan dilakukan atau bekas-bekas kejahatan lainnya, atau menariknya dari pemeriksaan yang dilakukan oleh pejabat kehakiman atau kepolisian maupun oleh orang lain, yang menurut ketentuan undang-undang terus- menerus atau untuk sementara waktu diserahi menjalankan jabatan kepolisian.

9. Pasal 222 "Barang siapa dengan sengaja mencegah, menghalang-halangi atau menggagalkan pemeriksaan mayat forensik, diancam dengan pidana penjara paling lama sembilan bulan atau pidana denda paling banyak empat ribu lima ratus rupiah".

10. Pasal 223 "Barang siapa dengan sengaja melepaskan atau memberi pertolongan ketika meloloskan diri kepada orang yang ditahan atas perintah penguasa umum, atas putusan atau ketetapan hakim, diancam dengan pidana penjara paling lama dua tahun delapan bulan".

11. Pasal 224 "Barang siapa dipanggil sebagai saksi, ahli atau juru bahasa menurut undang-undang dengan sengaja tidak memenuhi kewajiban berdasarkan undang-undang yang harus dipenuhinya, diancam":

1. dalam perkara pidana, dengan "pidana penjara paling lama sembilan bulan;

2. dalam perkara lain, dengan pidana penjara paling lama enam bulan.

12. Pasal 225 "Barang siapa dengan sengaja tidak memenuhi perintah undangundang untuk menyerahkan surat-surat yang dianggap palsu atau dipalsukan, atau yang harus dipakai untuk dibandingkan dengan 


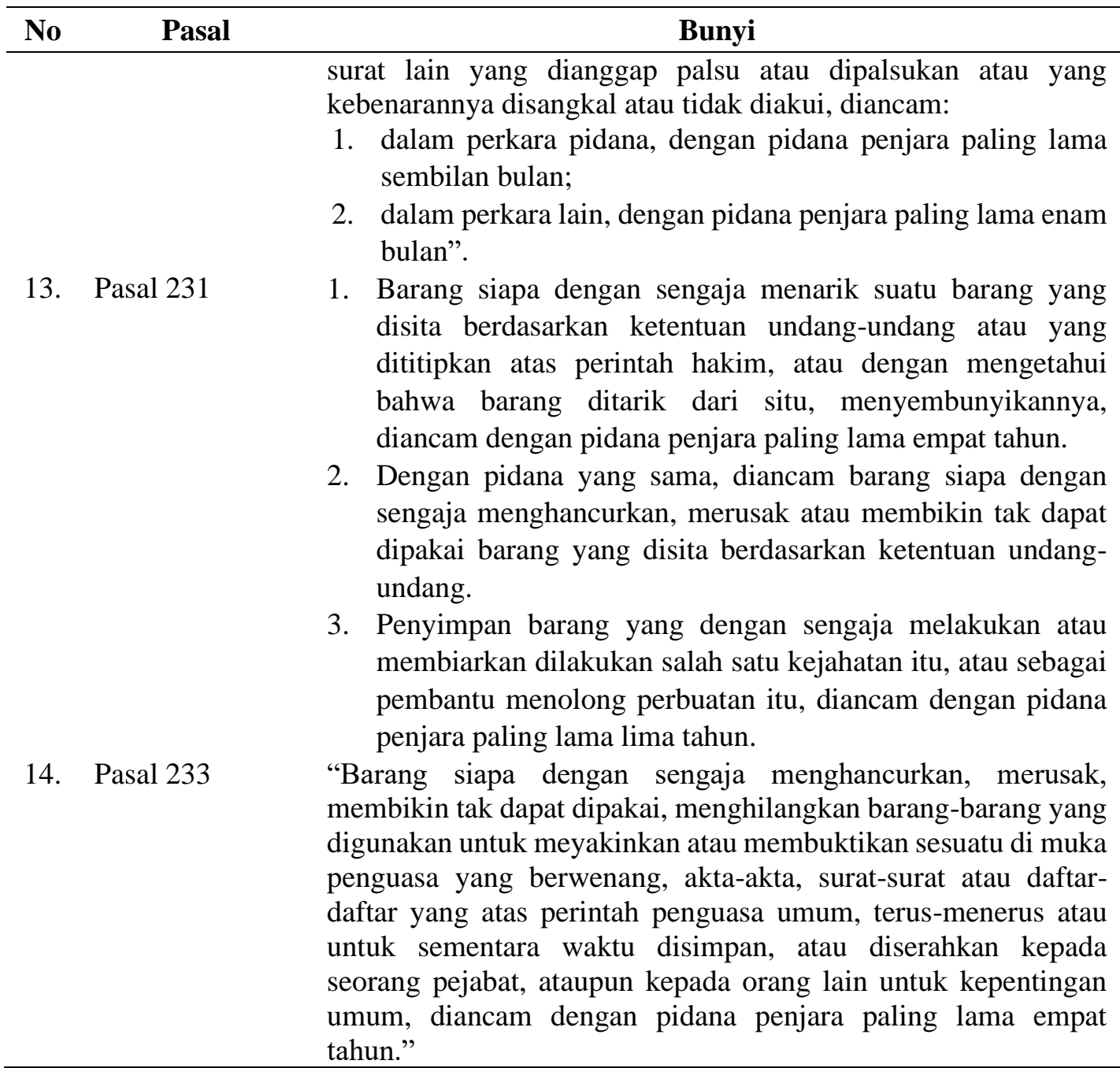

Rumusan tindak pidana lain yang berkaitan dengan tindak pidana korupsi pada Pasal 21 UndangUndang Nomor 31 Tahun 1999 jo. Undang-Undang Nomor 20 Tahun 2001:

"Setiap orang yang dengan sengaja mencegah, merintangi,atau Menggagalkan secara langsung atau tidak langsung penyidikan, penuntutan, dan pemeriksaan di sidang pengadilan terhadap tersangka atau terdakwa ataupun para saksi dalam perkara korupsi”.

Adapun suatu perbuatan dalam tindak pidana ini harus memenuhi unsur-unsur setiap orang; dengan sengaja; mencegah, merintangi, atau menggagalkan; secara langsung atau tidak langsung; penyidikan, penuntutan, dan pemeriksaan di sidang pengadilan; dan tersangka atau terdakwa ataupun para saksi dalam perkara korupsi.

Maka hal ini perlu dilakukan penafsiran gramatikal bahwa dalam analisa penulis menghilangkan alat bukti yang termasuk sebagai kasus Obstruction Of Justice tidak terdapat pembatasan sehingga demikian aparat penegak hukum dapat menafsirkan secara berbeda-beda maka perlu dijelaskan maksud dari mencegah, merintangi, dan menggagalkan yakni:

Perbuatan-perbuatan tersebut tidak dapat dipisahkan dengan unsur-unsur kesengajaann yang mendahului perkataan atau unsur mencegah, merintangi, atau menggagalkan tersebut. Artinya, disamping perbuatan itu dikehendaki, juga ada tujuan yang ingin dicapai dari masing-masing perbuatan itu.

1. Perbuatan mencegah ialah perbuatan dengan cara bagaimanapun yang tujuannya agar tidak terjadi sesuatu in casu penyidikan, penuntutan, atau pemeriksaan di sidang pengadilan. Secara singkat mencegah adalah segala ikhtiar agar tidak terjadi sesuatu. Pada perbuatan mencegah ada syarat, yakni sesuatu itu in casu penyidikan, penyidikan, penuntutan, dan pemeriksaan tindak pidana korupsi terhadap sesorang belum terjadi dan agar tidak terjadi, 
maka dilakukanlah perbuatan mencegah, misalnya menyuruh si pembuat atau saksi melarikan diri keluar negeri dengan memberi fasilitas-fasilitas dan kemudahan kepadanya. ${ }^{6}$

2. Berbeda halnya dengan perbuatan merintangi memerlukan syarat bahwa sesuatu telah terjadi. Agar sesuatu itu tidak terjadi berkepanjangan sampai pada suatu akhir yang tidak menyenangkan atau sesuatu yang tidak kehendaki, maka perlu dilakukan perbuatan merintangi. Jadi, perbuatan merintangi adalah segala ihktiar atau perbuatan dengan cara apa pun yang bersifat menggangu atau megahalangi sesuatu. Dalam hal ini telah dilakukan penyidikan, atau penuntutan, atau pemeriksaan di sidang pengadilan perkara korupsi. Agar penydikan, penuntutan, ataupun pemeriksaan di sidang pengadilan menjadi terhambat, terhalang tidak lancar, terganggu, atau kesulitan mencari alat bukti, maka dilakukan perbuatan merintangi. Misalnya memberikan uang kepada saksi yang memberatkan untuk melarikan lari keluar negeri, atau menyembunyikan, atau memengaruhinya dengan segala sesuatu. Misalnya dengan memberinya uang atau mengancamnya agar tidak memberikan keterangan yang memberatkan, dan sebagainya, ${ }^{7}$

3. Sedangkan perbuatan menggagalkan adalah segala perbuatan dengan cara apa pun yang mejadi penyebab gagalnya sesatu, yang secara singkat dapat disebut menjadikan gagal. Ini berupa perbuatan yang antara kehendak yang dicapai bersesuaian dengan akibab gagalnya sesuatu in casu penyidikan, penuntutan, dan pemeriksaan perkara korupsi, dengan akibat kegagalan dari tiga pekerjaan hukum tersebut dalam hukum formil korupsi tersebut hubungan causal. Penyebabnya adalah perbuatan menggagalkan dan mengakibatkan kegagalan penyidikan, penuntutan, dan kegagalan dalam pemeriksaan perakara korupsi ${ }^{8}$

4. Adapun yang dimaksud dengan kalimat "secara langsung atau tidak langsung" untuk menghindari celah hukum yang dapat digunakan oleh si pembuat untuk berkelit atau membebaskan dirinya dengan alasan perbuatannya bukan penyebab dari tidak terjadinya, terhambatnya atau gagalnya pemeriksaan perkara-perkara korupsi. Langsung dimaksudkan, antara perbuatan yang diwujudkan dengan tidak sampai dilakukannya, terhalang, atau gagalnya penyidikan, penuntutan atau pemeriksaan sidang pengadilan mempunyai hubungan langsung atau menjadi penyebab langsung, misalnya alat bukti kunci atau saksi kunci dihilangkan atau disuruh menghilang. Hal itu berakibat pada tidak dapat dilakukannya penyidikan, penuntutan, atau pemeriksaan perkara korupsi di sidang pengadilan, ${ }^{9}$

5. Sebaliknya perkataan "tidak langsung" berupa perbuatan dengan cara apa pun yang tidak secara langsung menimbulkan akibat tidak terjadinya atau terhambatnya atau gagalnynya penyidikan, penuntutan, atau pemeriksaan perkara korupsi disidang pengadilan. ${ }^{10}$

Bahwa menurut hemat penulis tindakan penyidik yang diduga menghilangkan alat bukti merupakan salah satu upaya Obstruction of Justice dengan melakukan pencegahan agar tidak ditindaklanjuti kasus tersebut dan tidak dapat dihukum orang yang sedang diusut oleh lembaga penegak hukum, penulis sependapat dengan Adami Chazawi bahwa dengan pemeriksaan tindak pidana korupsi terhadap sesorang belum terjadi dan agar tidak terjadi, maka dilakukanlah perbuatan mencegah, ${ }^{11}$ dan perbuatan secara langsung dilakukan yang dimaksud langsung terjadi gagalnya pemeriksaan perkara korupsi, sehingga pasal yang dapat dikenai ialah Pasal 21 Undang-Undang Nomor 31 Tahun 1999 jo. Undang-Undang Nomor 20 Tahun 2001 tentang Pemberantasan Tindak Pidana Korupsi. Dengan menerapkan pasal tersebut dapat memberika efek jera harapannya penyidik agar menjaga profesionalitas dan integritas yang dimiliki.

${ }^{6}$ Adami Chazawi, "Hukum Pidana Korupsi Di Indonesia (Edisi Revisi)," Jakarta: PT. Raja Grafindo Persada, 2016.

${ }^{7}$ Chazawi.

${ }^{8}$ Chazawi.

${ }^{9}$ Chazawi.

${ }^{10}$ Chazawi.

${ }^{11}$ Chazawi. 


\section{SIMPULAN}

Berdasarkan yang dikemukakan oleh penulis dengan didukung oleh pendapat ahli, maka dapat disimpulkan bahwa penyidik yang diduga menghilangkan alat bukti merupakan upaya obstruction of justice, hal ini disebabkan karena perbuatan menghilangkan alat bukti merupakan tindakan pencegahan agar tidak ditindak lanjutin kasus baik belum atau sedang diproses, sehingga telah patut diberlakukan pasal 21 Undang-Undang Nomor 31 Tahun 1999 jo. Undang-Undang Nomor 20 Tahun 2001 tentang Pemberantasan Tindak Pidana Korupsi, saran penulis untuk KPK, Kepolisian, dan Kejaksaan agar berani menindak anggotanya dan memperketat pengawasan penyimpanan alat bukti dari tingkat penyelidikan hingga mengadili karena sebenarnya alat bukti tersebut tidak menutup kemungkinan dapat dikembangkan menjadi kasus baru.

\section{DAFTAR PUSTAKA}

Agustina, Shinta. "Obstruction of Justice: Tindak Pidana Menghalangi Proses Hukum Dalam Upaya Pemberantasan Korupsi." Themis Books, 2015.

Anwar, Yesmil, and Adang. "Sistem Peradilan Pidana: Konsep, Komponen \& Pelaksanaannya Dalam Penegakan Hukum Di Indonesia.” Widya Padjadjaran, 2009.

Black, Henry Campbell, Bryan A Garner, Becky R McDaniel, David W Schultz, and West Publishing Company. Black's Law Dictionary. Vol. 196. West Group St. Paul, MN, 1999.

Chazawi, Adami. "Hukum Pidana Korupsi Di Indonesia (Edisi Revisi)." Jakarta: PT. Raja Grafindo Persada, 2016.

Doyle, Charles. "Obstruction of Justice: An Overview of Some of the Federal Statutes That Prohibit Interference with Judicial, Executive, or Legislative Activities." Library of Congress, Congressional Research Service, 2014.

https://www.idntimes.com/news/indonesia/santi-dewi/penyidik-kpk-malah-diperiksa-polisi-perusakanbarang-bukti-buku-merah/full, diakses Pukul 13.08, 08 Februari 2019

https://legal-dictionary.thefreedictionary.com/Obstruction+of+Justice

Undang-Undang Nomor 31 Tahun 1999 jo. Undang-Undang Nomor 20 Tahun 2001 tentang Pemberantasan Tindak Pidana Korupsi

Undang-Undang Nomor 8 Tahun 1981 tentang Hukum Acara Pidana.

Kitab Undang-Undang Hukum Pidana. 